3. Jeffares N., Dictionary of pastellists before 1800. Rosalba Carriera. URL: http://www.pastellists.com/articles/carriera.pdf (Last accessed: 20.11.2020)

4. Rosalba Carriera. Die Staatlichen Kunstsammlungen. Dresden, Germany. URL: https://skd-online-collection.skd.museum/Home/Index?page $=1 \& q=$ rosalba\%20carriera (Last accessed: 20.11.2020)

5. Rosalba Carriera. Cleveland Museum of Art, Cleveland, Ohio, USA. URL: http://www.clevelandart.org/art/1940.1203_Last accessed: 20.11.2020)

6. Rosalba Carriera. Fondazione Federico Zeri online. URL: http://catalogo.fondazionezeri.unibo.it/scheda/opera/67983/Carriera\%20Rosal ba $\% 2 \mathrm{C} \% 20$ Abbraccio\%20di\%20Giustizia\%20e\%20Pace (Last accessed: 20.11.2020)

7. Rosalba Carriera. Metropolitan Museum of Art, New York, USA. URL: https://www.metmuseum.org/art/collection/search/435854___Last accessed: 20.11.2020)

8. Rosalba Carriera. Treccani. Enciclopedia Italiana di Scienze, Lettere ed Arti online. URL: http://www.treccani.it/enciclopedia/rosalbacarriera_\%28Dizionario-Biografico\%29/_(Last accessed: 20.11.2020)

9. Rosalba Carriera. The Royal Collection, London, UK. URL: https://www.rct.uk/collection/420544/self-portrait-as-innocence (Last accessed: 20.11.2020)

10. Rosalba Carriera. Victoria and Albert Museum, London, UK. URL: http://collections.vam.ac.uk/item/O72539/portrait-miniature-of-robert-lordminiature-carriera-rosalba-giovanna/\#_(Last accessed: 20.11.2020)

DOI https://doi.org/10.30525/978-9934-26-004-9-44

\title{
ТЕХНІКА СГРАФІТО В СУЧАСНОМУ ЦЕРКОВНОМУ МИСТЕЦТВІ: ПРИКЛАДИ І ПЕРСПЕКТИВИ ЗАСТОСУВАННЯ
}

\author{
Вільховецька К. В. \\ аспірантка кафедри дизайну \\ Київського національного університету культури і мистецттв \\ м. Київ, Украӥна
}

Техніка сграфіто - один з перших способів зображення, що пережив безліч трансформацій і пристосувань, у кожен період часу показуючи широкий спектр можливостей застосування, і сьогодні не втрачає своєї актуальності. Зародилась як спосіб декорування в античній кераміці, 
закріпила за собою функцію архітектурного декору в епоху Відродження та проявилась як могутній інструмент монументальної пропаганди в 20-му столітті.

Сграфіто (італ. Sgraffito «видряпування») - техніка стінопису, суть якої полягає в послідовному нанесенні тонких кольорових шарів вапняно-піщаного, вапняно-цементно-піщаного або цементно-піщаного розчинів 3 барвниками на архітектурну площину. Зображення створюється шляхом зняття спеціальними інструментами свіжих верхніх шарів сирої штукатурки до розкриття нижніх. Зазвичай нижній шар, найтемніший по тону, це умовно - «тінь», а верхній - «світло», але можливі варіації. Класична версія - 2-шарове сграфіто, але поширені і 3-5-шарові.

Історично оздоблення технікою сграфіто було цариною радше цивільної архітектури, аніж сакральної, хоч останні теж присутні в світовому мистецтві. Цікавим зразком застосування сграфіто в церковному просторі $є$ роботи британського художника й ілюстратора Джорджа Хейвуда Самнера (1853-1940), тісно пов'язаного з рухом Мистецтв і ремесл (Arts and Crafts movement). Він використовув сграфіто в оформленні фасадів та інтер'єрів вікторіанських храмів. Його оригінальне авторське рішення - робити нижній шар штукатурки 3 декількох частин різних кольорів, що надавало закінченій роботі колірного різноманіття [1, с. 56].

Чи не найвідомішим прикладом сграфіто Дж. X. Самнера в храмовому просторі є оздоблення Англіканської церкви Всіх Святих в Лондоні (Ennismore Gardens, London ). Будівля, зведена за проектом Льюїса Вулліама в 1848-1849 роках повторює базиліку Сан-Дзено Маджоре у Вероні (XI ст.). Вражаючою є композиція із зображенням Розп'яття та символами євангелістів у арці над апсидою, а також шість медальйонів у західній частині храму, що символізують шість днів Творення. Наразі, храм є власністю общини зарубіжної єпархії Російської Православної Церкви, яка 31956 року почала орендувати храм i проводити богослужіння під окормленням талановитого місіонера отця Антонія (Блума), пізніше - митрополита Сурозької єпархії. Церква освячена на честь Успіння Богородиці та стала соборною [2].

В цьому аспекті цікавим $є$ ще й пристосування англіканського храму для служіння общини вже східного обряду. Оздоблення стін у техніці сграфіто, а також вітражі авторства Дж. Х. Самнера були відреставровані й доповнені образами для іконостасу від учнів видатного іконописця Леоніда Успенського , тож у цілому храм $є$ зразком гармонійного 
поєднання не тільки різних мистецьких технік, творів різних епох $\mathrm{i}$ стилів, а й конфесій.

В Україні становлять інтерес зразки сграфіто у Львові, що датуються переважно 30-ми роками XX століття. Вони створені в період нового етапу зацікавленням сграфіто 3 погляду техніко-технологічної та естетичної форми декору архітектури. Найцінніші і складні у реалізації фігуративні композиції, прикладом таких у Львові $є$ панно, створені у 60-ті роки ХХ століття на вулиці Й. Сліпого, 11 [3, с. 180]. В більшості сграфіто $\epsilon$ елементом декору і було створено ремісниками, чиї імена невідомі. Однак є поодинокі роботи, наділені рисами індивідуального виконання - як от композиції яскравого представника Art deco Казимира Пьотровича (1907-1980 рр.), випускника художньопромислової школи у Львові [4, с. 15-17].

Дослідження львівської спадщини сграфіто допомогло зрозуміти, що важливим етапом на шляху пізнання цієї техніки є докладне технікотехнологічне дослідження кожного окремого об'єкта, оскільки не доцільно виводити однотипну технологію виконання, коли стан поверхні архітектурної площини, методи роботи, пропорції розчинів та якість матеріалів у кожному випадку відрізняються .

В практиці сучасного українського церковного мистецтва застосування сграфіто не поширене, хоча вважається, що ця техніка використовувалась ще давньоруськими майстрами i $\epsilon$ традиційно близькою. На жаль сграфіто у більшості досі асоціюється зі спадщиною радянського монументального мистецтва й сприймається виключно як інструмент пропаганди, результат не творчості, а сухого виконання держзамовлення.

Проте, досвід радянського монументального живопису важливий та цінний, окрім інших аспектів, прикладами застосуванням різних комбінацій сграфіто 3 іншими способами стінопису: альфреско, мозаїкою, інкрустацією кольорового тиньку, 3 різьбленим або відформованим рельєфом з цементу чи гіпсу, з використанням присипки мармурової крихти, цегли, кераміки, скла тощо. Радянські монументалісти, починаючи 3 1960-х років, продемонстрували широкий спектр можливостей застосування i варіацій техніки, що може бути джерелом натхнення для сучасних стінописців, в тому числі майстрів сфери церковного мистецтва, для пошуку нових рішень й способів вираження.

У вищих художніх навчальних закладах України студентів знайомлять із технікою й технологією сграфіто : у Львівській національній академії мистецтв (на кафедрі сакрального мистецтва), в 
Харківській академії дизайну мистецтв (Кафедра монументального живопису), у Національній академії образотворчого мистецтва і архітектури (майстерня монументального живопису проф. О.В. Кожекова) та ін.

Натхненна прикладом радянських монументалістів, студентка ХДАДМ (станом на 2012 р. - прим. автора) Вільховецька К.В. реалізувала проект оздоблення воріт храму Св. Арх. Михаїла в селі Крути, що на Чернігівщині, 3 поєднанням сграфіто та мозаїки із керамічної плитки. Центром фризу є образ Спаса Нерукотворного у візантійському стилі, у техніці 4-х шарового сграфіто, від якого розходяться гілки виноградної лози, що вирізьблені у техніці 2-х шарового сграфіто, прикрашені листям та гронами, що викладені 3 керамічної плитки 3 додаванням смальти. Це технічне рішення було оптимальним для екстер'єру, а також - більш доступним для сільського приходу.

Таке поєднання технік та матеріалів $є$ вигідним в багатьох аспектах. По-перше, образи у візантійському стилі легко адаптувати для виконання в техніці сграфіто через графічність і чіткий тональний розподіл, а сама техніка дає більшу виразність тонкій графіці, «читабельність» 3 великої відстані, що для екстер'єру є значною перевагою. По-друге, технологічно таке поєднання є більш міцним та довговічним.

Такі експерименти демонструють нові перспективи застосування давніх технік, адаптованих до сучасних потреб за допомогою поєднання старих рецептів, сучасних матеріалів, цікавих композиційних та колористичних рішень, що сприятиме новому звучанню навіть давно знайомих, традиційних образів і сюжетів.

\section{Література:}

1. Д.В. Губарев. Монументальная техника сграффито : основные этапы развития. Декоративное искусство $u$ предметнопространственная среда. Вестник МГХПА им. С.Г. Строганова. 2019. № 3-1, C. 52-64.

2. https://suroz.russian-albion.com/ru/surojskaya-eparhiya/sobor-uspeniyabojiey-materi-i-vseh-svyaty

3. Радомська В.Р., Ніконова М.І. Сграфіто. Проблеми дослідження та збереження в архітектурному середовищі м. Львова. Національний університет «Львівська політехніка», кафедра дизайну та основ архітектури. 2010. № 674, С.178-183.

4. П. Гранкін Сграфіто у Львові. Будуємо інакше. 2000. № 3, С. 15-17. 